\title{
Hvor ble det av
}

\section{sykepleiehåndverket?}

Dagens sykepleie fokuserer på kvantitet fremfor kvalitet. Den håndverksmessige sykepleien er erstattet med prosedyrer , med liten tid til omsorg for pasienten.

\section{Forfatter}

\section{Mette Karoliussen}

Førstelektor og lærebokforfatter

Høgskolen i Sørøst-Norge, Porsgrunn

\section{Nøkkelord}

\section{praksis Sykepleiefaget Fagutvikling}

Sykepleien 2017 105(64089)(e-64089)

DOI: https://doi.org/10.4220/Sykepleiens.2017.64089

\section{HOVEDBUDSKAP}

Sykepleiefaget har gjennomgått mange strukturelle endringer over tid, som også har forandret den sykepleien pasientene får. Sykepleiehåndverket er mindre påaktet og mindre tilgjengelig enn tidligere, selv for svært syke pasienter. Denne praksisen koster både lidelse og penger. Hvor står sykepleiefaget i dag, og i hvilken retning bør faget utvikle seg videre? Praksisfeltet og utdanningene bør stå sammen om å løfte fram sykepleiedisiplinens praxis som et viktig og nødvendig element i pasientomsorgen.

Som besøkende eller pårørende til pasienter i sykehus og sykehjem har jeg i lang tid gjort observasjoner som har undret meg. Som interessert fagperson har denne undringen ført til et ønske om at sykepleiefagets tilstand drøftes bredere, både i utdanningene og helseinstitusjonene. 
Sykepleiefaget har vært offer for mange strukturelle forandringer. Noen har vært brå og vanskelige, og noen har gått nesten upåaktet hen. Felles for dem er at både sykepleierne og underviserne har måttet forholde seg til nye systemiske krav som har endret pasientomsorgen deres.

Jeg tror likevel tiden er inne til å se på sykepleiefagets status og vurdere hvordan sykepleiere kan gå sammen om å beskytte og videreutvikle sykepleien til pasientene.

\section{Mer medisinsk sykepleie}

En av observasjonene mine er at det kan virke som at den «gode» sykepleien til pasienten blir mindre viktig enn den medisinske behandlingen. Den terapeutiske sykepleien finnes fremdeles i noen spesialavdelinger og på hospice. Der er det høyere sykepleiekompetanse, større sykepleiedekning og bedre tid, noe som dessverre er mindre vanlig for pasienter på sykehus og sykehjem.

Dette gjelder også selv om pasienten er svært syk. Det er ikke bare trist, men også kostbart.

Forskningsresultatene fra ny helseforskning viser at deler av pasientomsorgen som sykepleie skal ta ansvar for, er svært viktige for pasienters rehabilitering, forebygging av komplikasjoner og gjenvinning av helse (1-4). Derfor vil en mangel på tilstrekkelig sykepleie både direkte og indirekte påvirke pasientens helse og sykdom (5).

\section{Ønsker debatt}

Med denne artikkelen ønsker jeg å inspirere til en faglig refleksjon som forhåpentligvis kan bidra i debatten om sykepleiefagets tilstand i våre helseinstitusjoner og påvirkning på pasientomsorgen. 
Jeg vil benytte og forklare begrepet

«sykepleiehåndverket». Ikke sjelden er dette begrepet

erstattet med ord som prosedyrer eller gjøremål.

Kanskje noen til og med tenker at de er synonyme

begreper. Ofte drilles sykepleiere i prosedyrer eller

gjøremål.

\section{三 «Ofte drilles sykepleiere i prosedyrer eller gjøremål.»}

Forstå meg rett: Det er viktig å kunne det man skal gjøre, og øvelse er alltid nødvendig. Drilling kan være nødvendig, men er absolutt ikke tilstrekkelig for at det blir sykepleiehåndverk.

\section{Disiplinens praxis}

Et håndverk er et arbeid som er fagmessig og profesjonelt utført. Det krever kunnskaper og kyndighet, og i sykepleiesammenheng krever det et godt håndlag. Det vil si kunnskaper og ferdigheter i hvordan hånden best kan brukes, noe som inkluderer et sykepleieklinisk blikk som kan styre håndens arbeid.

Vi ser her to dimensjoner i handlingen: I tillegg til at arbeidet utføres, som er et kvantitativt krav, kommer det en kvalitetsdimensjon som viser hvordan arbeidet blir gjort. Dette er mer enn det å få utført prosedyren eller gjøremålet. Også Florence Nightingale var opptatt av både å utføre handlingen og måten handlingen ble utført på $(6,7)$.

Sykepleiedisiplinens praxis innebærer noe mer enn bare å utføre handlingen, altså praksis. Praxis med x kan defineres som handlinger som er utført av en kunnskapsrik og reflektert person. 
Her er det også en etisk dimensjon. Når det gjelder sykepleie, utføres praxis av en sykepleier som ivaretar sykepleiedisiplinens kunnskaper, verdier og intensjoner i selve handlingen (8). Sykepleieren har hele sin oppmerksomhet på personen. Sykepleieren benytter sin kunnskap og sitt kliniske blikk når vedkommende med sikker hånd og innøvde teknikker tilpasser sine handlinger rolig og med forståelse for situasjonen (9-11).

\section{Dårligere kvalitet}

Nå vet jeg selvfølgelig at det er mange dyktige sykepleiere ute i felten, men det er likevel for lite tid og oppmerksomhet på sykepleiepraxis i helseinstitusjonene våre. Sykepleierne har det travelt og må utføre oppgavene med oppmerksomhet på kvantitet heller enn kvalitet. Med det mener jeg at en sykepleier kan bli kritisert for ikke å utføre et gjøremål, som for eksempel stell eller medisinutdeling.

Imidlertid blir de sjelden kritisert for måten disse gjøremålene blir utført på. Pasienter skal være informert, men forstår ikke alltid det sykepleierne informerer om. Problemet er at det ikke tas høyde for at det er i den kvalitative dimensjonen at sykepleie er terapeutisk og påvirker pasientens helse positivt. All tilstedeværelse av helsepersonell påvirker pasienten, men slett ikke alltid i en terapeutisk retning (12).

Som tidligere underviser og skribent har jeg reflektert mye over hva grunnene kan være til at sykepleiehandlingene fortrenges og lar seg fortrenge. Jeg vil peke på noen av dem her.

\section{Mangel på helhet}

Sykepleiere er kanskje en av de yrkesgruppene som snakker mest om at mennesket er en helhet. Likevel virker det som om forståelsen av helhet mangler. I hvert fall mangler helheten som viser at mennesket opplever og reagerer på sine omgivelser, og at opplevelsene gir fysiologiske reaksjoner. 
Alle burde vite dette. Alle som har fått spyttsekresjon ved lukten av sitron, hatt nervøs mage, blitt tørr i munnen eller rødmet i spesielle situasjoner.

Denne typen helhet viser den levende kroppens respons på personens opplevelser. Hva er det da som gjør at vi ikke forstår at pasientens opplevelser og reaksjon på det vi gjør og er, også får en fysiologisk respons? Denne responsen kan være bra eller dårlig for pasientens helsetilstand, og den skal ikke ignoreres.

Likevel ser det ut til at helsepersonell generelt er uoppmerksomme på at det de gjør og er, får konsekvenser for pasienten, - fysiologiske konsekvenser som påvirker helse og sykdom.

\section{Objektivitetens svøpe}

I helsevesenet har anerkjennelsen av subjektivitet hatt dårlige kår i lang tid nå. Det er kjent at vitenskapen har søkt å opprettholde en idé om en objektiv sannhet som har rotfeste i eksperimentet. I dag settes det søkelys også på denne objektiviteten.

Men viktigere her er at denne ideen har blitt tatt ut av sitt opprinnelige felt og transplantert inn på områder der den ikke hører hjemme. Den er transplantert inn i pasientomsorgen på utallige måter, både i den direkte pasientbehandlingen og i organisering og administrasjon. Det er avgjørende for pasientens helse at vi forstår at pasientens, så vel som vår egen subjektivitet, påvirker den terapeutiske situasjonen.

Ofte velger helsepersonell, også sykepleiere, å ta avstand fra subjektiviteten ved å holde en viss objektiv distanse. Og pasientens helse kan lide under denne objektive distansen.

\section{¿ «Det er en udiskutabel og bevist sannhet at helse og sykdom er uløselig knyttet til personlige oppfatninger og erfaringer.»}


Det er en udiskutabel og bevist sannhet at helse og sykdom er uløselig knyttet til personlige oppfatninger og erfaringer, og er derved subjektive størrelser (13, 14). Det er dessuten rikelig med beviser på at pasientens subjektivitet har betydning for sykdom og helse (15-17).

Ifølge Nightingale innebærer sykepleie også å beskytte pasientens subjektivitet, og derved sikre at forholdene ligger til rette for at pasientens tilstand er best mulig. På den måten kan sykepleieren sikre at behandlingen og rehabiliteringen får best mulige vilkår. Det vil si at pasientens helbredende krefter kan få rom til å virke (18). Dette er essensen i sykepleie, ikke bare i faget, men også i samfunnets forventning til sykepleiepraksis.

\section{Sykepleie versus medisin}

Medisinsk behandling hviler på sin objektivitet med basis i vitenskapen. Legene utfører arbeidet ut fra denne objektiviteten. Men medisinsk behandling er ikke sykepleie, og sykepleie er ikke minimedisin. Selv om både leger og sykepleiere forholder seg til samme pasient, er virksomheten deres ikke identisk. På det beste er arbeidet felles og komplementært.

\section{三 «Men medisinsk behandling er ikke sykepleie, og sykepleie er ikke minimedisin.»}

Terapeutisk sykepleie understøtter og hjelper pasienten

til å få best mulig utbytte av den helbredende virksomheten disse fagfeltene skal gi i fellesskap.

Medisinen har aldri begrunnet eller legitimert

sykepleien, selv om fagene berører hverandre. 
De to fagfeltene har mange felles basisfag, men begge har kunnskap som strekker seg utover den andre disiplinen. Medisin skal begrunne medisinsk behandling, og det greier legene godt. Det er sykepleien som skal begrunne sykepleie til pasientene. Og om vi søker objektivitet i vår forskning, bør objektiviteten ikke ha oppmerksomheten i sykepleien til pasienten. Det er uheldig for pasientenes helse.

\section{Ro gir hvile}

Den gamle «Nightingale-sykepleien» ble ivaretatt langt opp på 50-tallet - mest gjennom sykepleierhandlingene, men også gjennom sin måte å være på, kalt værens dimensjon. Denne dimensjonen ble sterkt vektlagt $(6,11)$.

Så sent som på 60-tallet hevdet sykepleielærere tydelig utsagn som «pasienten skal ha ro og hvile for sin sjel». I dag kan dette utsagnet belegges og begrunnes med ny helseforskning og er uomtvistelig viktig for helse og rehabilitering. Undervisningen som ble gitt den gang, viser også tydelig en anerkjennelse av forbindelsen mellom pasientens ytre og indre verden: «Ro ute hvile i sjelen».

Men på et udefinert tidspunkt, kanskje samtidig med ønsket om å begrunne sykepleien med forskning, ble oppmerksomhet forandret til gjøremål: «Sett tøflene på plass», «fjern unødige ting på nattbordet», «hold rommet ryddig». Ingen begrunnelse ble nevnt for hvorfor disse handlingene skulle gjøres - ei heller noen henvisning til pasientens subjektive opplevelse eller helse.

\section{Begrunnelser falt bort}

Nå er også disse «formaningene» falt bort, med det resultatet at det både er støy og uorden i pasientenes nærhet. De faglige begrunnelsene skiftet etter hvert karakter og lente seg mer mot den medisinske behandlingen. 
Senere, for å komme vekk fra medisinen, ble handlingene begrunnet i samfunns- og humanvitenskap. Resultatet var at sykepleien endret beskaffenhet, tømtes for viktig sykepleiekunnskap og mistet sitt særpreg.

I diskusjoner, også blant sykepleiere, ble slike kvalitative forhold ofte avvist som bakstreverske og lite effektive. Noen ganger ble de også oppfattet som romantiseringer av den «gamle» sykepleien.

I dag, derimot, har vi håndfaste, vitenskapelige beviser på at denne kvalitative sykepleien i seg selv er terapeutisk og hjelper pasienter til helbredelse. Derfor kan vi både bevise og begrunne sykepleiehåndverkets betydning i pasientomsorgen, nettopp som terapeutisk virksomhet for pasientenes helse og rehabilitering (19).

\section{Må ta faglig ansvar}

Aldri før har sykepleiefaget hatt den

forskningsmessige muligheten til å belegge, bevise og begrunne viktigheten av den håndverksmessige sykepleien til pasienten som nå for tiden (20). Det er flere fagfelt som bidrar til slik forskning, først og fremst psyko-nevro-immunologien, som viser forholdet mellom opplevelser, hjernebiokjemi og immunapparat (20).

Denne forskningen viser mekanismene mellom våre opplevelser og kroppens fysiologiske respons. Den viser også hvordan opplevelser påvirker helse og sykdom.

Også andre forskningsfelt er nyttige, som for eksempel humanøkologi, som viser hvordan mennesker påvirkes av det fysiske og sosiokulturelle miljøet de er en del av (21), samt kommunikologi, som viser menneskets kommunikasjon med seg selv og med andre mennesker $(22,23)$. 
Forskningsresultatene fra disse fagfeltene kan hjelpe sykepleiere tilbake til kjernen av sykepleiedisiplinen, nemlig hvordan sykepleiehåndverket har betydning for interaksjonen mellom sinn og kropp hos pasienter, og hvordan disse interaksjonene påvirker helse og sykdom.

Denne kjernen i sykepleien er mye viktigere for pasientenes helse og rehabilitering enn vårt helsevesen later til å forstå. Å rehabilitere denne forståelsen vil også bidra positivt til helseøkonomien. Den måten pasientene behandles på i dag, er økonomisk krevende.

\section{三 «Sykepleie er ingen abstrakt, teoretisk virksomhet, den er et bærekraftig håndverk.»}

Sykepleieres egen forskning er viktig og nødvendig, men kanskje ikke tilstrekkelig for å få innført sykepleiehandlinger som ivaretar pasientenes subjektivitet, og beskytter deres opplevelser slik at fysiologien blir helsefremmende. Ansvaret for å få dette til, ligger både i praksis og i utdanningsløpene. Sykepleie er ingen abstrakt, teoretisk virksomhet, den er et bærekraftig håndverk.

\section{Konklusjon}

Det er kostbart på flere måter at sykepleiere både får liten tid til å utføre sykepleiehåndverket, og lar være å kreve mer tid til pasientomsorgen. Pasienter trenger gode sykepleiere som har tid til å forholde seg til pasienten som subjekt, nettopp for å sikre best mulig helseresultat.

Effektivitet innebærer at målet nås på best mulig måte, og det er ikke det samme som høyt tempo. Noen ganger er høyt tempo ødeleggende for rehabilitering og gjenvinning av helse. Det er heller ikke økonomisk lønnsomt. 
Det er også kostbart med høyt sykefravær hos sykepleiere på grunn av frustrasjon og mangel på mulighet til å gjøre det som er etisk forsvarlig. Både i lidelse og penger er dette systemet uhensiktsmessig og kanskje for dårlig. Sykepleiedisiplinens medlemmer må gå sammen for å få til en forandring.

\section{Referanser}

1. Antoni MH. Stress management, PNI, and disease. I: Segerstrom S. (red) The Oxford Handbook of Psychoneuroimmunology. Oxford: Oxford University Press; 2012 (s. 385-420).

2. Glaser R, Kiecolt-Glaser JK. Stress-induced immune dysfunction: implications for health. Nature Reviews Immunology 2005;5(3):243-51.

3. Lutgendorf SK, De Geest K, Bender D, Ahmed A, Goodheart MJ, Dahmoush L et al. Social influences on clinical outcomes of patients with ovarian cancer. Journal of Clinical Oncology 2012;30(23):2885-90.

4. Webber MA. Psychoneuroimmunological outcomes and quality of life. Transfusion and Apheresis Science 2010;42:157-61.

5. Anderson S. Deadly consequences: The hidden impact of America's nursing shortage. Tilgjengelig fra: http://www.nfap.com/pdf/0709deadlyconsequences.pdf (nedlastet 03.11.2017).

6. Nightingale F. Notes on nursing; what it is, and what it is not. London: Harrison, Pall Mall; 1859.

Tilgjengelig fra: https://archive.org/details/notesonnursingnigh00nigh (nedlastet 13.11.2017).

7. Elstad I. Sjukepleietenkning. Oslo: Gyldendal Akademisk; 2014. 
8. Bawden R. Praxis: The essence of systems for being. I: Viskovic AR (red.). Research and development in higher education. Volume 14. Society of Australasia Campbelltown, Australia; 1993 (s. 1-7).

9. Weiss SJ. «Touch». I: Fitzpatric JJ (red.). Research on nursing practice. New York: Annual Review of Nursing Research 1988;6:3-27.

10. Karoliussen M. Sykepleie - tradisjon og forandring. En humanøkologisk tilnærming. Oslo: Gyldendal Akademisk; 2002.

11. Karoliussen M. Nightingales arv - ny forståelse. Oslo: Gyldendal Akademisk; 2011.

12. Jensen KB. Practical theories: Concepts, conceptions and conceptualizations of communication. European Journal for the Philosophy of Communication 2016;7(2):143-156.

13. Bawden R. Messy issues, worldviews and systemic competencies. I: Blackmore C (red.). Social learning systems and communities of practice. London: Springer; 2010 (s. 89-101).

14. Kirkengen AL. Skam og avmakt i medisinske møter. I: Gulbrandsen P, Fugelli P, Wilmar B, Stang GH (red). Skam i det medisinske rom. Oslo: Gyldendal Akademisk; 2006 (s. 65-85).

15. Zachariae R. Psychoneuroimmunology: A biopsycho-social approach to health and disease. Scandinavian Journal of Psychology 2009;50(6):64551.

16. Kirkengen A-L. Hvordan krenkede barn blir syke voksne. Oslo: Universitetsforlaget; 2005. 
17. Kelly-Irving M, Mabile L et al. The embodiment of adverse childhood experiences and cancer development: potential biological mechanisms and pathways across the life course. International Journal of Public Health 2013;58(1):3-11.

18. Kiecolt-Glaser JK, Heffner KL, Glaser R, Malarkey WB, Porter K, Atkinson C et al. How stress and anxiety can alter immediate and late phase skin test responses in allergic rhinitis.

Psychoneuroendocrinology 2009;34(5):670-80.

19. Dhabhar F. Effects of stress on immune function: the good, the bad, and the beautiful. Immunologic Research 2014;58(2):193-210.

20. Halldorsdottir S. A psychoneuroimmunological view of the healing potential of professional caring in the face of human suffering. International Journal for Human Caring 2007;11(2):32-9.

21. Antoni MH. Psychosocial intervention effects on adaptation, disease course and biobehavioral processes in cancer. Brain Behavior and Immunity 2013;30:S8898.

22. Feldman DF. Introduction to human ecology. 2006. Tilgjengelig fra: http://hornacek.coa.edu/dave/welcome.to.COA.06.pdf (nedlastet 01.11.2014).

23. Lanigan RL. Communicology: towards a new science of semiotic phenomenology. Cultura International Journal of Philosophy of Culture and Axiology 2007;4(2):212-16. 